University of Arkansas, Fayetteville

ScholarWorks@UARK

Education Reform Faculty and Graduate

Students Publications

Education Reform

$1-24-2017$

\title{
State and District Fiscal Effects of a Universal Education Savings Account Program in Arkansas
}

Julie R. Trivitt

University of Arkansas, Fayetteville, JTRIVITT@WALTON.UARK.EDU

Corey A. DeAngelis

University of Arkansas, Fayetteville

Follow this and additional works at: https://scholarworks.uark.edu/edrepub

Part of the Educational Assessment, Evaluation, and Research Commons, Educational Leadership Commons, and the Other Educational Administration and Supervision Commons

\section{Citation}

Trivitt, J. R., \& DeAngelis, C. A. (2017). State and District Fiscal Effects of a Universal Education Savings Account Program in Arkansas. Education Reform Faculty and Graduate Students Publications. Retrieved from https://scholarworks.uark.edu/edrepub/16

This Article is brought to you for free and open access by the Education Reform at ScholarWorks@UARK. It has been accepted for inclusion in Education Reform Faculty and Graduate Students Publications by an authorized administrator of ScholarWorks@UARK. For more information, please contact scholar@uark.edu. 


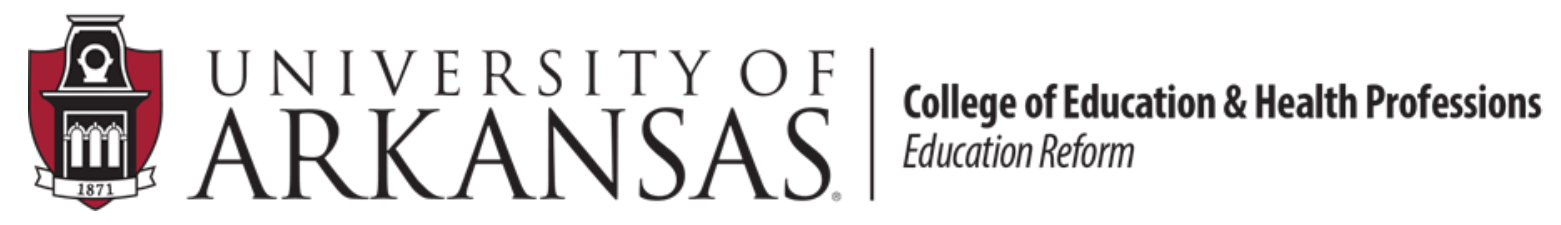

\section{WORKING PAPER SERIES}

\section{State and District Fiscal Effects of a Universal Education Savings Account Program in Arkansas}

Julie R. Trivitt, Ph.D.

Corey A. DeAngelis

January 24, 2017

EDRE Working Paper 2017-04

The University of Arkansas, Department of Education Reform (EDRE) working paper series is intended to widely disseminate and make easily accessible the results of EDRE faculty and students' latest findings. The Working Papers in this series have not undergone peer review or been edited by the University of Arkansas. The working papers are widely available, to encourage discussion and input from the research community before publication in a formal, peer reviewed journal. Unless otherwise indicated, working papers can be cited without permission of the author so long as the source is clearly referred to as an EDRE working paper. 


\title{
STATE AND DISTRICT FISCAL EFFECTS OF A UNIVERSAL EDUCATION SAVINGS ACCOUNT PROGRAM IN ARKANSAS
}

\author{
Julie R. Trivitt, Ph.D. \\ Walton College of Business, \\ University of Arkansas \\ JTrivitt@walton.uark.edu \\ Corey A. DeAngelis \\ Department of Education Reform, \\ University of Arkansas \\ cadeange@uark.edu
}

January 24, 2017

School Choice Demonstration Project,

University of Arkansas, Fayetteville, AR

\section{Acknowledgements}

The content of the report is solely the responsibility of the authors and does not necessarily represent the views of the University of Arkansas. We thank Patrick J. Wolf for comments on previous drafts. All remaining flaws are our own. Corresponding author is Julie Trivitt, jtrivitt@walton.uark.edu. 


\begin{abstract}
Legislators in Arkansas have proposed a bill to increase educational choice through an Education Savings Account (ESA) program available to every child across the state. While many studies on the financial impact of existing ESA, voucher, and scholarship programs in the United States have found overall benefits to the state and individual districts, it may not be the case for a universally-accessible ESA since most existing programs are targeted to students based on need. A universal ESA would make ESAs available to all K-12 students in the state, so the fiscal impact is expected to be less beneficial than a targeted voucher or scholarship program.

We use the Arkansas state funding formula to estimate the net impact of the proposed ESA program on the state budget overall. We also use the state education expenditure report in order to estimate the impact on each public school district in the state. Using our most defensible set of assumptions, we find that a universally-accessible ESA would result in small financial benefits to the state overall and to about half of the individual public school districts.

Specifically, we estimate the program to result in around $\$ 2.8$ million in financial benefits to the state in the first year. Additionally, we find that 50.6 percent of districts would financially benefit, while 55.5 percent of individual student transfers would result in financial benefits to their local school districts.
\end{abstract}

Keywords: Private school; school choice; fiscal effects; school finance 


\section{Introduction}

There are four different types of private school choice, and sixty-one ${ }^{1}$ programs currently exist in over half of the states in the U.S. These include vouchers, tax credit scholarships, individual tax credit deductions, and Education Savings Accounts (ESAs). Each of these types of programs allow families to allocate additional funding to a private school of their choice. However, ESAs also allow families to use their funding for online learning programs, tutoring, educational therapy, and even college costs. Currently, five states have ESA programs: Arizona, Florida, Mississippi, Nevada, and Tennessee. However, none of the existing programs are fullyuniversal since they are targeted to students identified with special needs (Florida, Mississippi, \& Tennessee), or limit access to students that previously attended a public school (Arizona \& Nevada). None of the existing ESA programs receive their revenue through tax credits, even though they could be funded that way.

Arkansas is the first state to propose a fully-universal ESA in the United States. The proposed program would allow any child eligible to enroll in a K-12 public school in the state to qualify for the ESA. The highly-accessible program in Nevada is not fully-universal since it limits eligibility to children that previously attended a public school for at least 100 days before starting an ESA. In other words, families already sending their children to private school are not eligible. While this condition improves the fiscal impact of the program in the short-run, the long-run outcome is not affected since these programs allow students entering Kindergarten to participate. However, since the ESA proposed in Arkansas does not limit program access in this way, the potential financial impact is less likely to be overwhelmingly positive in the short-run.

\footnotetext{
${ }^{1}$ https://www.edchoice.org/school-choice/school-choice-in-america/
} 
Arkansas also is the first state to propose an ESA program funded by corporate and personal tax credits. The fact that tax expenditures, and not general government appropriations, would fund the initiative also affects its fiscal impact, in this case positively, for reasons we explain below.

\section{Literature Review}

The evidence on the impact of private school choice programs on student test scores is abundant and clear. Overall, private school voucher programs have small positive impacts on student achievement across the globe (Shakeel, Anderson, \& Wolf, 2016). The largest positive impacts are for reading scores and for programs outside of the United States. Of the fifteen experimental evaluations of voucher programs within the United States, thirteen have found null to positive effects on student test scores (Barnard, Frangakis, Hill, \& Rubin, 2003; Bettinger \& Slonim, 2006; Bitler, Domina, Penner, \& Hoynes, 2015; Cowen, 2008; Greene, 2000; Greene, Peterson, \& Du, 1999; Jin, Barnard, \& Rubin, 2010; Krueger \& Zhu, 2004; Peterson, Howell, Wolf, \& Campbell, 2003; Rouse, 1998; Wolf et al., 2013) and only two, both on the Louisiana Scholarship Program, have found negative effects on student achievement (Abdulkadiroglu, Pathak, \& Walters, 2015; Mills \& Wolf, 2016).

While there are fewer studies on longer-term outcomes such as graduation rates and citizenship skills, the findings are generally positive on those measures as well. A couple of studies find large positive impacts for graduation rates and college enrollment (Cowen et al., 2013; Wolf et al., 2013; Chingos \& Peterson, 2015). Private school choice also appears to have positive impacts on political participation (Fleming, 2014; Fleming, Mitchell, \& McNally, 2014), tolerance of others (Campbell, 2002; Fleming, Mitchell, \& McNally, 2014; Wolf, Peterson, \& 
West, 2001), charitable activity (Bettinger \& Slonim, 2006), and reduced criminal activity (DeAngelis \& Wolf, 2016; Deming, 2011; Dobbie \& Fryer, 2015).

Programs that generate these benefits to participants might be justified even if they come with a substantial cost to taxpayers. However, the financial tradeoff is not necessary with most school choice programs, as the studies of the fiscal impacts tend to find that private school choice programs require less taxpayer funding than paying for education in traditional public schools. In particular, these studies find that targeted voucher programs produce financial benefits to the state budgets overall since participating private school tuition levels are generally less than student funding amounts in traditional public schools (Costrell, 2010; Trivitt \& DeAngelis, 2016). Trivitt and DeAngelis (2016) found that elimination of the Louisiana Scholarship Program would result in a net loss to the state budget of around \$7.6 million per year. Martin Lueken (2016) found that ten tuition tax credit programs in the United States saved the state around $\$ 1,650$ to $\$ 3,000$ per scholarship student.

Additionally, studies have found that most local public school districts benefit since students leaving public schools are costlier to educate than the revenue lost from the state (DeAngelis \& Trivitt, 2016; Scafidi, 2012). DeAngelis and Trivitt (2016) found that over 80 percent of student transfers from private to public schools would result in financial losses for local public school districts if the Louisiana Scholarship Program was eliminated or reduced.

However, these studies all examined targeted programs and did not estimate the financial impact of an ESA. We estimate the effect that the proposed universal ESA program would have on state and district education funding in Arkansas. 


\section{Proposed Legislation}

The Arkansas Parental Empowerment for Education Choice Act of 2017 has been introduced in the Arkansas state legislature for the 2017 legislative session. ${ }^{2}$ This bill allows for the creation of a tax credit for contributions to approved 501(c)(3) non-profit organizations ${ }^{3}$ which use the donations to fund ESAs for students eligible to attend a public school in Arkansas. The students receive the ESA funds to attend a private school or purchase curriculum for homeschool studies in lieu of attending a public school. The amount contributed to the ESA is the foundation-funding amount for the year, which is set to \$6,646 in 2017.

If the number of students applying for an ESA exceeds the funding available, the ESA organizations are to prioritize current users and their siblings. If funds remain, new accounts are to be offered in a weighted random lottery that makes sure students who qualify for the national school lunch program are well represented among ESA users.

The bill allows a credit on state income taxes for contributions to ESA non-profits for individuals and corporations. There is a statewide limit of $\$ 10$ million in tax credits for 2017 . In subsequent years, the tax credit is limited to the amount needed to fund ESAs for all eligible applicants plus an additional $10 \%$.

\section{Data}

We use publicly-available data from the annual education funding statistics report ${ }^{4}$ provided by the Arkansas Department of Education for the 2014-15 school year. We also use the

\footnotetext{
${ }^{2}$ http://www.arkleg.state.ar.us/assembly/2017/2017R/Pages/Billnformation.aspx?measureno=HB1222

${ }^{3}$ We will refer to these simply as ESA non-profits throughout the rest of the report.

${ }^{4}$ http://www.arkansased.gov/divisions/fiscal-and-administrative-services/publication-andreports/report_categories/annual-statistical-reports
} 
2015-16 Arkansas school finance manual ${ }^{5}$ and the annual statistical report definitions from the Arkansas Department of Education for state and district funding formula details. We also use the 2014-15 Cycle 2 Report, ${ }^{6}$ publicly-available at the ADE Data Center website, in order to calculate each district's student composition and categorical funding.

Using data from the 2014-15 annual education funding statistics report, we analyze state and district financial impacts for 245 public school districts with a total of 435,556 students in attendance during that school year. Since student populations increase over time, we should expect our results to be a conservative estimate of the realized effect in the 2017-18 school year.

\section{Methods}

\section{State}

This fiscal impact of this bill is determined by the combination of decreases in tax revenue received with decreases in state funding transferred to local districts based on student enrollment. By introducing a tax credit for charitable contributions and providing ESAs to students, this bill will reduce both revenue and expenditures for the state. The net effect on the state is the difference between the reduction in state tax revenue and the reduction in education funding for students in traditional public schools:

\section{Net Effect on State $=($ Reduction in State Education Funding - Reduction in State Revenue $)$}

If the revenue forgone exceeds the funding no longer needed, the bill will have a negative fiscal impact on the state. However, if the revenue forgone is less than the funding no longer

\footnotetext{
${ }^{5}$ http://www.arkansased.gov/public/userfiles/Fiscal_and_Admin_Services/Publication\%20and\%20reports/Arkansa s_School_Finance_Manual/Arkansas_School_Finance_Manual_FY16.pdf

${ }^{6}$ https://adedata.arkansas.gov/statewide/Cycles/DistrictCyclez.aspx
} 
needed, the ESA will have a positive fiscal impact on the state. To calculate the expected fiscal impact on the state we begin by estimating the revenue foregone from this legislation.

The reduced revenue comes from the income tax credit for charitable contributions made to non-profit organizations to fund ESAs for eligible students. The amount of revenue foregone due to the credit varies considerably based on the filing status and tax bill of the donor. The basic characteristics of the tax credit are as follows: donations to a 501(c)(3) organization that have been approved by the state to fund ESAs qualify for a tax credit on Arkansas state income taxes. The amount of the tax credit is limited to $50 \%$ of tax liability, and using the contribution to qualify for the tax credit prevents a taxpayer from also deducting the contribution as a charitable donation on their state tax return. For corporations making the donation, the tax credit is reduced by the federal corporate income tax reduction resulting from the contribution. The federal tax savings will generally be equal to the contribution amount multiplied by the donor's marginal tax rate, so the tax savings triggered by the contribution are split between the federal and state income taxes. The higher the marginal tax rate the corporate donor is in, the larger the savings on the federal return, and the smaller the state tax credit will be.

Individuals face no such reduction in the state tax credit due to the federal corporate tax "piggy-back" and can use donations to eligible non-profits as a deduction on their federal return. Individuals can also claim the full tax credit on their state return. For individual taxpayers the combined federal and state tax savings can be larger than the original contribution.

We use a couple of simple hypothetical examples to illustrate the effects of contributions on state taxes. The first example is a corporation with $\$ 250,000$ in taxable income filing a return on federal form $1120^{7}$ and Arkansas form AR1100CT. ${ }^{8}$ We calculate the federal and state taxes

\footnotetext{
${ }^{7}$ This form is publicly-available online: https://www.irs.gov/pub/irs-pdf/f1120.pdf

${ }^{8} \mathrm{http}: / /$ www.dfa.arkansas.gov/offices/incomeTax/corporation/Documents/AR1100CT_2016_RE.pdf
} 
for this firm making a $\$ 10,000$ contribution to an ESA non-profit that qualifies for the tax credit, a $\$ 10,000$ contribution to another non-profit, and making no contribution. For simplicity, we assume the corporation generates all revenue and profits within Arkansas. The spreadsheet below shows the amounts that differ across the tax returns based on the line number that differs. A corporation with taxable income between $\$ 100,000$ and $\$ 335,000$ is in a $39 \%$ marginal tax bracket, and, as a result, saves $\$ 3,900(\$ 80,750-76,850)$ in federal income taxes when making a $\$ 10,000$ charitable contribution.

\section{Corporate Income Tax with ESA Tax Credit}

\section{Federal Income Tax}

Total income (line 11 on form 1120)

Charitable contribution (line 19)

Taxable income

Federal income taxes due

\section{Arkansas Income Tax}

Total Income

Charitable contribution

Taxable Income

State Tax

State tax credit for ESA

(contribution - Federal tax savings)

State Taxes Due

Combined Federal and State Taxes

Change in AR tax revenue from ESA credit

$$
\begin{array}{lcl}
\text { ESA } & \text { Another } & \text { No } \\
\text { Non-Profit } & \text { Non-Profit } & \text { Contribution }
\end{array}
$$

\begin{tabular}{rrr}
250,000 & 250,000 & 250,000 \\
10,000 & 10,000 & 0 \\
\hline 240,000 & 240,000 & 250,000 \\
& & \\
76,850 & 76,850 & 80,750
\end{tabular}

$\begin{array}{lcl}\text { ESA } & \text { Another } & \text { No } \\ \text { Non-Profit } & \text { Non-Profit } & \text { Contribution }\end{array}$

\begin{tabular}{rrr}
250,000 & 250,000 & 250,000 \\
0 & 10,000 & 0 \\
\hline 250,000 & 240,000 & 250,000 \\
15,190 & 14,540 & 15,190 \\
6,100 & 0 & 0 \\
\hline
\end{tabular}

$9,090 \quad 14,540 \quad 15,190$

$85,940 \quad 91,490 \quad 95,940$

$\begin{array}{rr}5,450 & 6,100 \\ (54.5 \%) & (61.0 \%)\end{array}$


The corporation also qualifies for a state tax credit under this bill if the contribution is made to a qualifying ESA non-profit. The tax credit reduces the state tax by $\$ 6,100$. This results in a total tax savings (federal and state combined) of $\$ 10,000$ for the $\$ 10,000$ contribution. From the state's perspective, the state tax collected as a result of this bill is reduced by $\$ 6,100$ relative to the counterfactual, where no contribution is made $(\$ 15,190-9,090)$. If ESA contributions are made as firms redirect charitable donations away from other organizations that do not qualify for the tax credit, then the unobserved counterfactual may be the alternative scenario, where the revenue foregone by the state is only $\$ 5,450(\$ 14,540-9,090)$.

If the donation to fund the ESA is made by a household, the effect on state revenue is slightly different since the household pays personal, rather than corporate, income taxes, so the tax credit provided by the state is not reduced. The tax paid on federal and state income taxes is determined by income, marital status, and the filing status chosen by the taxpayer. For this example, we use a household with a married couple filing a joint return since this is the most frequently used filing status. We use two married couples filing a joint return using form 1040 for their federal tax return and AR1000F for their state tax return. We assume the households itemize deductions rather than taking the standard deduction. We use one household with a $\$ 50,000$ taxable income and one with a $\$ 75,000$ taxable income. The mean adjusted gross income from tax returns filed by households in Arkansas was $\$ 50,378$ for the 2013 tax year (Urban Institute, 2016). While an income of $\$ 75,000$ is well above the median income for the state, the reality is that higher income households are in a better position to utilize the tax credit provision by making charitable contributions, especially since they are more likely to itemize their deductions. ${ }^{9}$

\footnotetext{
${ }^{9} \mathrm{http}: / /$ taxfoundation.org/blog/who-itemizes-deductions
} 
Again, we look at the differences in total income taxes paid for three different scenarios:

a contribution to an ESA non-profit, a contribution to another non-profit, and no charitable contribution for the year. The first table considers a household with $\$ 50,000$ in taxable income that makes a $\$ 1,000$ contribution. This household pays a $15 \%$ marginal tax rate on income at the federal level and $6 \%$ at the state level.

\section{Personal Income Tax with ESA Tax Credit}

Married filing jointly

and itemize deductions

AGI (line 37 form 1040)

Charitable Contribution (line 40)

Taxable income

Federal Income Taxes

\begin{tabular}{rrr} 
ESA & \multicolumn{1}{l}{ Another } & \multicolumn{2}{l}{ No } \\
Non-Profit & Non-Profit & \multicolumn{1}{l}{ Contribution } \\
50,000 & 50,000 & 50,000 \\
1,000 & 1,000 & 0 \\
\hline 49,000 & 49,000 & 50,000
\end{tabular}

$6,426 \quad 6,426$

6,576

Since the contribution to the ESA non-profit and other non-profit both qualify as charitable contributions to be listed on Schedule C, the household saves \$150 (15\%) in federal taxes by itemizing their deductions relative to making no contributions.

$\begin{array}{lll}\text { ESA } & \text { Another } & \text { No } \\ \text { Non-Profit } & \text { Non-Profit } & \text { Contribution }\end{array}$

\section{Arkansas Income Tax}

Total Income \& AGI (line $21 \& 23$ )

Charitable contribution (line25)

Taxable Income (line 26)

State Tax (line27)

State Tax Credit for ESA

AR Net Tax Due (line 36)

Combined Federal and State Taxes

Change in AR tax from ESA credit

For a $\$ 1,000$ ESA contribution

\begin{tabular}{rrr}
50,000 & 50,000 & 50,000 \\
0 & 1000 & 0 \\
\hline 50,000 & 49000 & 50000 \\
2,268 & 2,208 & 2,268 \\
1,000 & 0 & 0 \\
1,268 & 2,208 & 2,268 \\
7,694 & 8,634 & 8,844 \\
& & 1,000 \\
& 940 & $(100.0 \%)$
\end{tabular}


The household qualifies for a state income tax credit, and federal tax savings do not reduce the credit. In this case, the household's total tax obligation is reduced by $\$ 1,150$ ( $\$ 8,844$ - \$7,694) in combined federal and state taxes when contributing to an ESA eligible non-profit as opposed to a $\$ 210$ tax savings $(\$ 8,844-8,634)$ when contributing to another non-profit. In this case, the revenue forgone by the state because of the tax credit is close to the full amount of the contribution. It is $100 \%$ of the donation if it results in new charitable contributions and $94 \%$ if it displaces contributions to other organizations when the contribution is less than $50 \%$ of the state income tax liability.

According to 2013 tax data (Urban Institute, 2016), among Arkansas taxpayers who itemize deductions, the average charitable contributions claimed was $\$ 5,524$. This is likely more than $50 \%$ of the tax liability for many households, so consider another example for a household where the 50\% tax credit limit comes into play. In this case, the married couple has a taxable income of $\$ 75,000$ and makes a $\$ 2,500$ contribution to the ESA non-profit.

$\begin{array}{lrrr}\text { Married filing jointly } & \text { ESA } & \text { Another } & \text { No } \\ \text { and itemize deductions } & \text { Non-Profit } & \text { Non-Profit } & \text { Contribution } \\ \text { AGI (line 37 form 1040) } & 75,000 & 75,000 & 75,000 \\ \text { Charitable Contribution (line 40) } & 2,500 & 2,500 & 0 \\ \text { Taxable income } & 72,500 & 72,500 & 75,000 \\ & & & \\ \text { Federal Income Taxes } & 9,614 & 9,614 & 10,326\end{array}$

A married couple with a taxable income of $\$ 75,000$ pays a $28 \%$ marginal tax rate for federal income taxes and $6.5 \%$ for state. With a $\$ 2,500$ charitable deduction, the household saves $\$ 712$ in federal income taxes $(\$ 10,326-9,614)$. 


\section{Arkansas Income Tax}

Total Income \& AGI (line 21 \& 23)

Charitable contribution (line25)

Taxable Income (line 26)

State Tax (line27)

State Tax Credit for ESA

(limit of $50 \%$ of tax due)

AR Net Tax Due (line 36)

Combined Federal and State taxes

Change in AR tax revenue from ESA credit For a $\$ 2500$ ESA contribution $\begin{array}{lll}\text { ESA } & \text { Another } & \text { No } \\ \text { Non-Profit } & \text { Non-Profit } & \text { Contribution }\end{array}$

\begin{tabular}{rrr}
75,000 & 75,000 & 75,000 \\
0 & 2500 & 0 \\
\hline 75,000 & 72,500 & 75,000 \\
3762 & 3468 & 3762 \\
1,881 & 0 & 0 \\
\hline
\end{tabular}

\begin{tabular}{rrr}
1,881 & 3468 & 3762 \\
\hline 11,495 & 13,082 & 14,088
\end{tabular}

1,587

1,881

$(63.5 \%)$

The household qualifies for a tax credit from the ESA contribution, but only a partial tax credit, since it is limited to $50 \%$ of the state tax obligation. This means the household can get a maximum credit of $\$ 1,881$. This cap on the credit effectively reduces the revenue lost to the state. Now the $\$ 2,500$ contribution only reduces state revenue by $63.5 \%$ or $75.2 \%$, depending on whether it is a reallocation of another charitable contribution or a new contribution made by the household. Note that despite the cap limiting the state tax credit, the household has a net tax reduction of $\$ 2,593(\$ 14,088$ - 11,495) from a $\$ 2,500$ ESA contribution.

These are just three examples of potential tax changes resulting from the ESA tax credit. In these examples, the lost state revenue resulting from a $\$ 1$ ESA contribution ranges from a high of $\$ 1$, or $100 \%$, to a low of about 54.5 cents on the dollar, or $54.5 \%$. Since the tax credit cannot exceed the amount contributed, the upper limit will be $\$ 1$ in state revenue lost for $\$ 1$ contributed to the ESA non-profit. The lower limit would be less than 54.5 cents of revenue forgone per dollar contributed if corporations paying the highest marginal tax rate donate enough to have their credit limited to $50 \%$ of their state tax obligation. 
For corporations, we use a $65 \%$ loss of state revenue for each dollar contributed. That is based on a corporation facing a 35\% marginal tax rate for federal taxes and the contribution being a new charitable gift. This also assumes the corporation does not run into the $50 \%$ cap on the tax credit. For contributions made by households, we use an $80 \%$ average loss of state revenue for each dollar contributed. This recognizes that some households likely run into the tax credit cap and/or some of the contributions are reallocated from other charitable uses. The National Center for Charitable Statistics ${ }^{10}$ reports that on 2013 tax returns (the most recent year for which data is available) $23 \%$ of Arkansas taxpayers itemized deductions and the average charitable contribution claimed by those taxpayers was $\$ 5,224$ (Urban Institute, 2016).

If we use a $65 \%$ state revenue reduction for each dollar contributed by a corporation and an $80 \%$ state revenue reduction for each dollar contributed by a household, the overall reduction will depend on how the total contributions are split between households and corporations. Overall, in the US households provide $72 \%$ of all charitable contributions, suggesting that corporate entities make up the remaining $28 \%$. Some of the tax credit scholarship programs already in place have seen corporations make a slightly larger percentage of the contributions than this national average. This is likely due to differential tax incentives and the fact that households tend to contribute to religious organizations while corporations generally do not.

Georgia and Arizona are two states with tax systems similar to Arkansas that have previously passed legislation allowing tax credits for contributions to scholarship programs by households and corporations, and report information on scholarships funded or dollars donated by source.

\footnotetext{
${ }^{10}$ http://nccs.urban.org/database/overview-nccs-data-files
} 
Relative to Georgia and Arizona, Arkansas generates a larger percentage of state revenue from corporate income taxes and has the highest marginal corporate tax rate, which should give Arkansas firms a financial incentive to contribute to the ESA organizations. However, Arkansas taxpayers also have the highest marginal individual tax rate among the three states.

The table below shows some statistics about the income tax plans in all three states taken from Facts and Figures 2016: How Does Your State Compare? ${ }^{11}$

Table 1: Income Tax Comparison

\begin{tabular}{l|c|c|c|}
\multicolumn{2}{c}{ Arkansas } & Arizona & Georgia \\
\hline Corporate Income Tax & & & \\
Percent of local/state revenue & $3.70 \%$ & $2.90 \%$ & $2.40 \%$ \\
Highest marginal rate & $6.50 \%$ & $5.50 \%$ & $6 \%$ \\
Income at which it applies & $\$ 100,000$ & $\$ 0$ & $\$ 0$ \\
Per capita collections & $\$ 134$ & $\$ 85$ & $\$ 93$ \\
& & & \\
\hline Individual Income Tax & & & \\
Percent of local/state revenue & $24.60 \%$ & $15 \%$ & $26.40 \%$ \\
Highest marginal rate & $6.90 \%$ & $4.54 \%$ & $6 \%$ \\
Income at which it applies & $\$ 35,099$ & $\$ 150,000$ & $\$ 7,000$ \\
Per capita collections & $\$ 877$ & $\$ 515$ & $\$ 888$ \\
\hline
\end{tabular}

In Arizona, individuals and corporations can get tax credits for contributing to different scholarship funds. For the 2013-2014 school year, the funds that collect corporate contributions paid out $\$ 26,121,958$ in scholarships and the funds accepting individual contributions paid out $\$ 55,395,132$. In Arizona, the scholarships provided by household contributions were $68 \%$ of the total.

\footnotetext{
${ }^{11}$ http://taxfoundation.org/article/facts-figures-2016-how-does-your-state-compare
} 
In Georgia, each scholarship organization can take contributions from all donors and they report the total contribution amounts by donor type. In 2015, the scholarship funds received $\$ 39,784,245$ from individuals and $\$ 18,242,934$ from corporations. Here, households made $68.6 \%$ of donations to eligible scholarship organizations. Similar to the bill proposed in Arkansas, Arizona and Georgia both have a statewide cap on the tax credits that can be claimed from contributions to scholarship funds, plus an absolute, as opposed to percentage, limit per taxpayer that the bill proposed for Arkansas does not include.

To be conservative, we project $33 \%$ of total contributions will be made by corporations and $67 \%$ by households. The table below shows the state tax revenue lost per dollar contributed depending on the tax status of the donor.

Table 2: Revenue Dollars Lost for a \$1.00 ESA Contribution

\begin{tabular}{|c|c|}
\hline & $\begin{array}{c}\text { Revenue Lost for a } \$ 1.00 \text { ESA } \\
\text { Contribution }\end{array}$ \\
\hline Proportion of Revenue from Households & 0.763 \\
\hline $75 \%$ & 0.755 \\
\hline $70 \%$ & $\mathbf{0 . 7 5 1}$ \\
\hline $\mathbf{6 7 \%}$ & 0.748 \\
\hline $65 \%$ & 0.740 \\
\hline $60 \%$ & \\
\hline
\end{tabular}

We use an estimate of $\$ 0.75$ in state revenue lost for every $\$ 1$ contributed to an eligible ESA organization. Now that our assumptions have been described and justified, we can calculate the revenue lost for each ESA funded.

ESA Contribution (Foundation Funding) $\quad \$ 6,646$

State revenue lost per ESA funded $\$ 4,985$

(Foundation Funding* .75) 
Every ESA funded by the program requires $\$ 6,646$, which will reduce state revenue by $\$ 4,985$. There is no doubt that state revenue will be lower if the bill is passed. However, each student who receives an ESA will not be enrolled in public school and the state education funding needed will also be reduced. To determine the net effect on the state, we now consider how much less funding for public schools will be needed.

\section{Local School Funding}

Arkansas public schools, like most public schools in the United States, are funded by a combination of local, state, and federal funds. Arkansas uses a funding matrix to determine the foundation funding per student. This is the same foundation-funding amount that is deposited into ESAs for eligible students under this bill. The local district is expected to collect a minimum threshold of revenue based on the local property tax base and the state pays the difference needed to meet the foundation funding per student. The state then provides additional categorical funds for students with additional educational needs. The primary characteristics that warrant categorical funding are students who are not native English speakers, students educated in an alternative learning environment, and students eligible for free or reduced lunch prices through the national school lunch program. Other categorical funding is determined based on the number of students such as the professional development for faculty. Arkansas also provides additional funding for districts who see enrollment fluctuations, up or down, from the previous year.

When a student leaves a district to attend a private school, the property tax base is unchanged, therefore local tax revenue for schools does not change. The same local revenue is now spread out over fewer students which increases local funding per student. This reduces the 
need for state funding to meet the foundation funding and additional categorical funding based on student enrollment. We use the funding formula in the Arkansas School Finance Manual 2015-2016, ${ }^{12}$ and the foundation funding amount and categorical funding rates for the 2016-2017 school year, to estimate how much less state funding each district would require if it had one less student attending this year. The state funding no longer needed if one student leaves this district is $\$ 7,604$, but varies considerably based on the local revenue and student characteristics in the district. The minimum is $\$ 361$, the maximum is $\$ 10,966$ and the median is $\$ 7,646$.

Of course, not all districts are equally likely to have students opt out of public schools when offered an ESA. We use data ${ }^{13}$ on private school attendance from the most recent year of the Private School Universe Survey (PSS) to supplement our analysis. The PSS has data on private schools by address of each private school. We group schools and school districts for each of Arkansas's 75 counties. While the opportunity to home school is the same in all counties, the availability of private schools is clearly not equal. In Arkansas, private school attendance is quite low, with the number of private school students equal to only $5.6 \%$ of public school attendance. The percentage of private school students ranges from $0 \%$ (in 27 counties) to a high of $34.9 \%$ in Lee County. Since the state average is $5.6 \%$, we classify counties as having a high private school density if K-12 private school enrollment in the county is greater than $6 \%$ of public school enrollment. If we limit the costs avoided to districts where there is higher private school density, the average cost avoided by the state is $\$ 7,814$. There is still considerable variation, with a minimum of $\$ 801$, a maximum of $\$ 10,904$ and a median of $\$ 7,857$. These numbers represent the cost avoided by the state if a student uses an ESA to switch from a public

12 http://www.arkansased.gov/public/userfiles/Fiscal_and_Admin_Services/Publication\%20and\%20reports/Arkansas _School_Finance_Manual/Arkansas_School_Finance_Manual_FY16.pdf

${ }_{13}$ https://nces.ed.gov/surveys/pss/pssdata.asp 
school to a private alternative such as private school or homeschooling. Going forward, we refer to these students as "switchers."

If each ESA funded results in \$5,546 less tax revenue, but each student switcher who uses an ESA saves the state an average of $\$ 7,604$ or $\$ 7,814$, there appears to be a clear positive impact of more than $\$ 2,000$ for each student using an ESA who switches as a result of the bill. To be conservative, we use the lower amount, $\$ 7,604$, as the average funding reduction for students who switch from public schools. However, the wide eligibility of the bill allows students to utilize the program who are not switchers, a provision that must be factored into our calculations.

If a student currently attending private school utilizes an ESA, the state forgoes $\$ 4,985$ in revenue via the tax credit. However, if the student is not attending a public school (i.e. is not a “switcher"), the local district does not see a reduction in student enrollment and the state's education funding obligation is not reduced. This creates a net negative fiscal effect of $\$ 4,985$.

The net fiscal effect to the state is going to depend on how many ESAs go to switchers versus students already in private or homeschools. The first year tax credits on the program are limited to $\$ 10$ million. This will likely become a binding constraint on the program in the first year.

Since the tax credit is limited to $\$ 10$ million, and the tax credit represents revenue foregone, which we estimate to be $75 \%$ of contributions, that suggests a total of $\$ 13.33$ million would be contributed to ESA nonprofits before the cap is reached. Given the foundation funding of $\$ 6,646$ in 2017 , \$13.33 million would provide funding for 2,006 ESA students. The bill specifies that ESAs be awarded to applicants in the following manner:

1. Priority to ESA users from previous year 
2. Priority to siblings of ESA users in category 1

3. Eligible students on a waitlist from the previous academic year

4. Lottery among all other applications but weighted so that free/reduced lunch program (FRL) eligible students are equally represented among ESA users as in the state.

5. If FRL students are not equally represented in applicant pool, all FRL eligible students are awarded an ESA, and remaining applicants go into a random lottery. Since categories 1-3 will not exist in the first year of the program, the first year ESAs will be awarded beginning with category 4. In Arkansas, using student counts from the 2014-15 school year, $62 \%$ of public school students qualify for free or reduced lunches. Therefore, $62 \%$ of all ESAs awarded the first year should go to FRL-eligible students. If FRL students represent less than $62 \%$ of ESA applicants, then $100 \%$ of all FRL-eligible students who apply for ESAs will be awarded one.

Because FRL eligibility is based on household income, FRL-eligible students are highly unlikely to be already attending a private school and are almost certainly going to be switchers if awarded an ESA. Previous studies have shown no more than $10 \%$ of low-income households who apply for voucher programs are able to send their students when denied a voucher (Costrell, 2010; Mills \& Wolf, 2016). Even among students not eligible for FRL, the vast majority of current students in Arkansas attend public schools. The table below shows the net fiscal impact to the state based on the percentage of ESA students who are switchers if 2,006 ESAs can be funded the first year. Additionally, many students who come from families with incomes above the FRL eligibility are currently attending public schools and are likely to apply for ESAs if this program is passed. 


\section{Table 3: First Year Fiscal Impact}

\begin{tabular}{|l|l|}
\hline Percent Switchers & Net Fiscal Impact \\
\hline $100 \%$ & $\$ 5,255,291$ \\
\hline $90 \%$ & $\$ 3,729,762$ \\
\hline $\mathbf{8 4 \%}$ & $\mathbf{\$ 2 , 8 1 4 , 4 4 4}$ \\
\hline $80 \%$ & $\$ 2,204,233$ \\
\hline $70 \%$ & $\$ 678,704$ \\
\hline $60 \%$ & $(\$ 846,825)$ \\
\hline
\end{tabular}

This table makes it clear that the fiscal impact the first year is going to depend on who is awarded ESAs. The breakeven switcher rate is about $65.6 \%$. In other words, if at least $65.6 \%$ of ESA students are leaving public schools, the state will have a positive fiscal impact. If the percentage of switchers is less than $65.6 \%$, the overall fiscal impact will be negative. All students who are currently home schooled, or attending private school, have a financial incentive to apply for an ESA. ESA funds can be used for private school tuition, supplementary tutoring, online curriculum, and other approved expenses. In addition, any funds not needed the current year can be transferred into a college-savings account for the student. Even if the family does not want to track expenses and submit a receipt to be reimbursed from the ESA, the ability to add thousands of dollars to the student's college fund provides an economic incentive to participate in the program.

All students currently attending public schools who would prefer a private school, and would be able to attend with the ESA funds, also have an incentive to apply for an ESA. The low-income families who qualify for the FRL program are most likely to be unable to attend private school without the ESA funding. If the program is not well promoted among public school students, we project the switcher rate could be as low as $55 \%$ since the private school administrators and home school networks are highly likely to inform students and parents about the new option. If the program is well promoted and public school students know about the 
application process, we project $84 \%$ of first year users would be switchers and the net fiscal effect would be a gain of about $\$ 2.8$ million dollars to the state.

\section{District}

Thus far, all the fiscal effects discussed have been at the state level. Now we turn our attention to individual districts. Since we need to have accurate data on district expenditures, we use statistics from the 2014-2015 school year, the most recent year for which finalized school expenditures are available, to determine the costs districts incur and revenue provided by the state based on the number of students.

When the state experiences a net positive effect, it is because less funding is provided to local districts. This seems inherently harmful to districts until you consider that the district now needs less funding, as it will incur lower costs educating fewer students. At the district level, we compare changes in variable costs incurred to educate one additional student to changes in revenue tied to each transferring student.

In the long-run, or for large changes in student enrollment, all costs are variable. In the short-run, total costs can be divided into two categories: variable and fixed. Fixed costs are those that do not vary with small changes in student enrollment. In education, those would be costs such as administrator salaries, bus purchases, or building construction. Variable costs are those that do vary, even with small changes in the number of students. Some education costs that we would expect to be variable are food service ingredients, copy paper, and licenses for online instructional materials. In our analysis of short-run impacts, all costs are classified as either fixed or variable:

Total Costs $=$ Fixed Costs + Variable Costs 
We use the classification strategy employed by Benjamin Scafidi (2012) in order to differentiate between fixed and variable costs in public schools. Rather than letting accountants or administrators classify costs based on expected usage, Scafidi observed what districts did when faced with unexpected budget cuts to determine which costs are variable and which ones are not. We classify the following types of expenditures ${ }^{14}$ as variable: total instruction, student support services, food service operations, enterprise operations, and community operations. Using the expenditure patterns Scafidi documented, we classify the following types of expenditures as fixed: administration, central services, maintenance and operations, transportation, other district support, facilities, debt service, and other program costs. If it is not clear how the expenditure category on the report matches Scafidi's classifications, we assume the expenditure is fixed. Once the costs have been classified, we estimate the linear cost equation for each district of the form:

\section{Total Costs $=$ FC $+(A V C *$ Number of Students $)$}

The additional cost incurred by the district for a one-student change in enrollment is AVC (average variable cost). With a linear cost formula, AVC is also the marginal cost, or additional cost incurred to educate one additional student. When a student leaves a public school, this represents a savings or cost avoided. However, with fewer students to be educated, the local district will receive less revenue from the state.

Once we find the average variable costs per student for each district, using the 2014-15 Arkansas state finance reports, we compare them to the total state revenue lost from a student transferring to a private school. We use the following formula to determine each district's benefit or loss:

\footnotetext{
${ }^{14}$ We refer to current expenditures as "costs" since we assume spending is efficient in public schools.
} 


\section{Net Benefit $=($ Cost Avoided - Funding Reduction $)$}

If the cost avoided is greater than the funding reduction, the district experiences a net benefit as a result of the student leaving through using an ESA. If the costs avoided are less than the funding reduction, the net effect is negative and the district is worse off financially because of the enrollment decline.

To determine the funding reduction associated with a loss of one student, we utilize the funding formula to calculate the total state revenue with one less student and compare that number to the total state revenue with all current students for each district. The change in total revenue for one less student is, by definition, the marginal revenue for one student. The Arkansas school finance formula is comprised of state foundation funding, based on local property tax receipts, and state categorical funding, based on the number of students requiring additional expenses within the local district.

The state share of foundation funding per pupil is found by taking the foundation-funding amount $(\$ 6,561)$ and subtracting out the local revenue collected per pupil. Since a student transfer from a public to a private school in Arkansas will not change local property tax receipts, local revenue per pupil will increase. Since local revenue per student will increase, the state share of foundation funding will decrease.

Additionally, when a student leaves a public school, for whatever reason, the local district will lose categorical funding based on student classification. As outlined in the 2015-16 Arkansas School Finance Manual, districts receive categorical funding based on the number of students classified as needing an alternative learning environment, being an English language learner, and participating in the national school lunch program. The state also provides funding, based on student enrollment, for professional development, gifted and talented, career education, 
special education, early childhood programs, magnet programs, and other program aid. To calculate the reduced categorical funding, we assume that the leaving student looks like the "average" student in the district, based on student characteristics reported by the ADE Data Center in the 2014-15 cycle 2 enrollment report. ${ }^{15}$

We take both of these revenue reductions into account with our simulation. If the lost marginal costs associated with the policy change exceeds the lost revenue from the state, the school district benefits financially in the short-run. We ignore declining enrollment funding, even though districts receive additional funding for one year when students exit residentiallyassigned public schools. We also ignore the additional funding schools receive the first year when enrollment is increasing.

\section{District}

Table 2 provides descriptive statistics of the funding structures of the 245 traditional public school districts in Arkansas for the 2014-15 school year. On average, school districts have about two-thirds of costs classified as variable in the short run; but districts do vary in their funding structures and expenditure decisions. District shares of variable costs range from 33 to 78 percent, with a standard deviation of seven percent. On average, districts face around $\$ 7,800$ in variable costs associated with educating each student and receive $\$ 7,200$ from the state to cover those costs. So when students transfer out of public schools for any reason, the average district benefits financially by almost $\$ 600$.

\footnotetext{
${ }^{15}$ https://adedata.arkansas.gov/statewide/Cycles/DistrictCycle2.aspx
} 
Table 4: District Statistics

\begin{tabular}{|l|l|l|l|l|}
\hline Variable & Average & Std. Dev. & Min & Max \\
\hline Variable Costs & $67 \%$ & $7 \%$ & $33 \%$ & $78 \%$ \\
\hline Fixed Costs & $33 \%$ & $7 \%$ & $22 \%$ & $67 \%$ \\
\hline MC per pupil & $\$ 7,775$ & $\$ 1,106$ & $\$ 6,116$ & $\$ 13,966$ \\
\hline MR per pupil & $\$ 7,205$ & $\$ 1,863$ & $\$ 361$ & $\$ 10,832$ \\
\hline
\end{tabular}

As shown in Table 4, the average district is expected to financially benefit by $\$ 570$ per student exiting their public school as a result of the ESA. The figures above weight each district equally. When we weight each district by the number of students, the expected outcome is a \$914 financial benefit per ESA-using student, or about 10 percent of the average per-pupil spending in the state in 2014-15. In other words, each student transferring from a public to a private school in Arkansas will result in about \$914 in reduced variable costs to the district in excess of reduced funding from the state. The district that will face the largest financial benefit will lose $\$ 9,513$ more in variable costs than the amount of reduced state revenue, while the district that faces the largest financial loss is expected to have state revenue decrease by $\$ 3,170$ more than reduced variable costs. Districts that experience a negative net effect are structured so they are harmed financially when enrollment falls for any reason, including students leaving due to ESAs.

In the last two rows of Table 5, we report the percent of districts that benefit overall and the percent of student transfers that result in a benefit to their local school district. These numbers are close to 50\%, indicating that about half of the districts are likely to benefit while about half are harmed. Specifically, we find that 50.6 percent of districts benefit, while around 55.5 percent of individual student transfers result in financial benefits to their local districts. 
Table 5: District Fiscal Effects

\begin{tabular}{|l|cc|}
\hline Variable & \multicolumn{2}{|c|}{$\begin{array}{c}\text { Per Pupil } \\
\text { Result }\end{array}$} \\
\hline Expected Value (Districts Equally Weighted) & $\$$ & 570 \\
\hline Expected Value (Student Weighted) & $\$$ & 914 \\
\hline Maximum Benefit & $\$$ & 9,513 \\
\hline Maximum Loss & $\$$ & 3,170 \\
\hline Standard Deviation & $\$$ & 2,278 \\
\hline Percent of Districts Benefitting & $50.6 \%$ \\
\hline Percent of Student Transfers Causing Benefit & $55.5 \%$ \\
\hline
\end{tabular}

\section{Discussion and Policy Implications}

Arkansas may be the first state to pass a fully-universal ESA. Although this is an unprecedented policy proposal, the impacts on the state and local district education budgets are expected to be small. In particular, we expect that the state will face a small financial benefit of around $\$ 2.8$ million in the first year, or around a tenth of a percent of its overall education budget. Furthermore, we expect that about 55.5 percent of student transfers will result in financial benefits to their local school districts from being liberated from the costs of educating children in excess of the lost state education revenues. On average, a student transferring from a public to a private school is expected to result in over a $\$ 900$ benefit to their local school district.

The fiscal impact to the state the first year is sensitive to the percentage of ESA users who switch sectors. In the long-run, the results should be less sensitive to switchers for a few reasons. 1.) Only about half of the private school students in the U.S. stay in private schools until graduation. To the degree that the ESA keeps the students who would have returned to public in private schools, the fiscal effect is the same as if the student switched. 2.) As new students reach Kindergarten age once the program is in place, they are typically eligible for the program, and switching status is irrelevant. If they decide to use an ESA to enter a private 
school instead of enrolling in a public school, then the state benefits fiscally just as if they had switched from public to private school.

There are also a couple of significant benefits with this bill that we have not attempted to measure, but should not be ignored. Any households with students already in a private school who are awarded ESAs will see an increase in spending power. This is also true for individuals who contribute and see a combined federal and state tax savings that exceeds their contribution. They may spend more of their household income on other consumption once the ESA program is in place. At the very least, the program will lead to a higher standard of living for program donors and participants and will likely generate local economic growth. Secondly, private school tuition and online homeschool curricula can be purchased for less than the foundationfunding amount. The bill states all ESAs will be funded with the foundation amount, and it specifically authorizes investing in college funds as an appropriate use of ESA dollars. If this bill is passed, students graduating from private schools through the ESA program in the near future will have more money saved for college than they would have had otherwise. This development would likely contribute to increased educational attainment for these students, generating enhanced benefits for the individual, the state, and the rest of society for many years to come. 


\section{References}

Abdulkadiroglu, A., Pathak, P. A., \& Walters, C. R. (2015). School vouchers and student achievement: evidence from the Louisiana Scholarship Program (No. w21839). National Bureau of Economic Research.

Barnard, J., Frangakis, C. E., Hill, J. L., \& Rubin, D. B. (2003). Principal stratification approach to broken randomized experiments: A case study of school choice vouchers in New York City. Journal of the American Statistical Association, 98(462), 299-323

Bettinger, E., \& Slonim, R. (2003). The effect of educational vouchers on academic and nonacademic outcomes: Using experimental economic methods to study a randomized natural experiment. Mimeo, Case Western Reserve University.

Bettinger, E., \& Slonim, R. (2006). Using experimental economics to measure the effects of a natural educational experiment on altruism. Journal of Public Economics, 90(8), 16251648.

Bitler, M., Domina, T., Penner, E. K., \& Hoynes, H. (2015). Distributional effects of a school voucher program: Evidence from New York City. Journal of Research on Education Effectiveness, 8(3), 419-450.

Campbell, D. E. (2002). The civic side of school reform: how do school vouchers affect civic education? Center for the Study of Democratic Politics Working Paper. Retrieved from http://www.princeton.edu/csdp/events/Campbell041702/campbell2.pdf.

Chingos, M., \& Peterson, P. E. (2015). Experimentally estimated impacts of school vouchers on college enrollment and degree attainment. Journal of Public Economics 122(2), 1-12.

Costrell, R. M. (2010). The fiscal impact of the Milwaukee Parental Choice Program: 2010-2011 update and policy options. SCDP Milwaukee Evaluation. Report\# 22. School Choice Demonstration Project.

Cowen, J. M. (2008). School choice as a latent variable: Estimating the "complier average causal effect" of vouchers in Charlotte. Policy Studies Journal, 36(2), 301-315.

Cowen, J. M., Fleming, D. J., Witte, J. F., Wolf, P. J., \& Kisida, B. (2013). School Vouchers and student attainment: Evidence from a state-mandated study of Milwaukee's Parental Choice Program. Policy Studies Journal, 41(1), 147-168.

DeAngelis, C. A., \& Trivitt, J. R. (2016). Squeezing the public school districts: The fiscal effects of eliminating the Louisiana Scholarship Program. EDRE Working Paper No. 2016-10.

DeAngelis, C., \& Wolf, P. J. (2016). The school choice voucher: a get out of jail card? EDRE Working Paper 2016-03. Available at SSRN: https://ssrn.com/abstract=2743541. 
Deming, D. (2011). Better schools, less crime? The Quarterly Journal of Economics, 2063-2115.

Dobbie, W., \& Fryer Jr, R. G. (2015). The medium-term impacts of high-achieving charter schools. Journal of Political Economy, 123(5), 985-1037.

Fleming, D. J. (2014). Learning from schools: School choice, political learning, and policy feedback. Policy Studies Journal, 42(1), 55-78.

Fleming, D. J., Mitchell, W., \& McNally, M. (2014). Can markets make citizens? School vouchers, political tolerance, and civic engagement. Journal of School Choice, 8(2), 213236.

Greene, J. P. (2000). The effect of school choice: An evaluation of the Charlotte children's scholarship fund program. Manhattan Institute for Policy Research Civic Report, (12).

Greene, J. P., Peterson, P. E., \& Du, J. (1999). Effectiveness of school choice: The Milwaukee experiment. Education and Urban Society, 31(2), 190-213

Howell, W. G., Wolf, P. J., Campbell, D. E., \& Peterson, P. E. (2002). School vouchers and academic performance: Results from three randomized field trials. Journal of Policy Analysis and Management, 21(2), 191-217.

Jin, H., Barnard, J., \& Rubin, D. B. (2010). A modified general location model for noncompliance with missing data revisiting the New York City school choice scholarship program using principal stratification. Journal of Educational and Behavioral Statistics, 35(2), 154-173.

Krueger, A. B., \& Zhu, P. (2004). Another look at the New York City school voucher experiment. American Behavioral Scientist, 47(5), 658-698.

Lueken, M. F. (2016). The tax-credit scholarship audit: Do publicly funded private school choice programs save money? EdChoice.

Mills, J. N., \& Wolf, P. J. (2016). The effects of the Louisiana Scholarship Program on student achievement after two years. Available at SSRN 2738805.

Peterson, P. E., Howell, W. G., Wolf, P. J., \& Campbell, D. E. (2003). School vouchers: Results from randomized experiments. In Caroline M. Hoxby (Ed.), The Economics of School Choice (pp. 107-144). University of Chicago Press.

Rouse, C. E. (1998). Private school vouchers and student achievement: An evaluation of the Milwaukee Parental Choice Program. Quarterly Journal of Economics, 113(2), 553-602.

Scafidi, B. (2012). The Fiscal Effects of School Choice Programs on Public School Districts. National Research. Friedman Foundation for Educational Choice. 
Shakeel, M., Anderson, K. P., \& Wolf, P. J. (2016). The participant effects of private school vouchers across the globe: A meta-analytic and systematic review. EDRE Working Paper No. 2016-07. Available at SSRN: https://ssrn.com/abstract=2777633.

Trivitt, J. R. \& DeAngelis, C. A. (2016). The Fiscal Effect of Eliminating the Louisiana Scholarship Program on State Education Expenditures. EDRE Working Paper No. 201606. Available at SSRN: https://ssrn.com/abstract=2768956.

Urban Institute. (2016). Profiles of individual charitable contributions by state 2013. Available at http://www.urban.org/research/publication/profiles-individual-charitable-contributionsstate-2013.

Wolf, P. J., Peterson, P. E., \& West, M. R. (2001). Results of a school voucher experiment: The case of Washington, DC after two years. KSG Working Paper No. RWP02-022. Available at SSRN: https://ssrn.com/abstract=313822.

Wolf, P. J., Kisida, B., Gutmann, B., Puma, M., Eissa, N., \& Rizzo, L. (2013). School vouchers and student outcomes: Experimental evidence from Washington, DC. Journal of Policy Analysis and Management, 32(2), 246-270. 


\begin{abstract}
About the Authors
Julie R. Trivitt is a Clinical Assistant Professor in the Department of Economics at the University of Arkansas in Fayetteville. Her research focuses on teacher effectiveness, noncognitive measures of abilities in academic achievements, and the evaluation of school choice programs. She received her Ph.D. in Economics from the University of Arkansas in 2006.

Corey A. DeAngelis is a Distinguished Doctoral Fellow and Ph.D. student in Education Policy at the University of Arkansas in Fayetteville. His research focuses on the effects of school choice programs on student achievement and non-academic outcomes. He additionally holds a Bachelor of Business Administration and a Master of Arts in Economics from the University of Texas at San Antonio.
\end{abstract}

\begin{abstract}
About the SCDP
Housed within the Department of Education Reform at the University of Arkansas, the School Choice Demonstration Project (SCDP) is an education research center dedicated to the nonpartisan study of the effects of school choice policy. Led by Dr. Patrick J. Wolf, the SCDP's national team of researchers, institutional research partners and staff are devoted to the rigorous evaluation of school choice programs and other school improvement efforts across the country. The SCDP is committed to raising and advancing the public's understanding of the strengths and limitations of school choice policies and programs by conducting comprehensive research on what happens to students, families, schools and communities when more parents are allowed to choose their child's school. Reports from past SCDP studies are available at http://www.uaedreform.org/school-choice-demonstration-project/.
\end{abstract}

